\title{
Adoption of Improved Maize Varieties as a Sustainable Agricultural Intensification in Eastern Ethiopia: Implications for Food and Nutrition Security
}

\author{
Mengistu Ketema $^{1, a^{*},}$, Kibebew Kibret ${ }^{2, b}$, Feyisa Hundessa ${ }^{3, c}$, Tewodros Bezu ${ }^{4, d}$ \\ ${ }^{1}$ School of Agricultural Economics and Agribusiness, Haramaya University. Postal address: 138, Dire Dawa, Ethiopia \\ ${ }^{2}$ School of Natural Resources Management and Environmental Sciences, Haramaya University, Ethiopia. \\ ${ }^{3}$ School of Animal and Rangeland Sciences, Haramaya University, Ethiopia. \\ ${ }^{4}$ School of Plant Sciences, Haramaya University, Ethiopia. \\ *Corresponding author
}

A R T I C L I N F O A B S T R A C T

Research Article

This paper examines factors determining farmers' adoption decision for improved maize varieties in the maize-common bean intercropping practices in two districts of East Hararghe zone, Eastern Ethiopia. It is based on data collected from 129 farm households using structured questionnaire. Descriptive results revealed that adopters of improved maize varieties had better food and nutrition

Received : 29/09/2020

Accepted : 16/02/2021 security status. Furthermore, logit model output indicated that the decision to adopt improved maize varieties is influenced by location (district) dummy, education status of the household head, age of the household head, distance from the main road, and the number of plots owned. Major recommendations include improving the rural road infrastructure, educating and training farmers, organizing experience sharing events among farmers, and raising awareness about the food and

Keywords:

Sustainable practices nutrition security benefits of sustainable agricultural intensification practices like intercropping Intensification

Food security

Adoption

Maize varieties

\section{Introduction}

In Ethiopia, agriculture contributed about 33.3 percent of the Gross Domestic Product in 2018/19 (NBE, 2019) and employs more than three-quarters of the population serving as a major source of livelihoods. The main development agenda of Ethiopia, the second most populous country in Africa, is related to ensuring food security and poverty eradication. Ensuring food and nutrition security mainly depends on the performance of the country's agriculture sector. However, the performance of this sector remained very week where the major manifestation is its low level of productivity. As a result, the country has been continuously confronted with the challenge of feeding its growing population. Hence, there should be a means to speed up agricultural output so as to meet the potential demand. However, the growing demand for food cannot be met from area expansion since that has already become a minimal source of output growth. There should be an increment in crop output per unit of land. This could be achieved through agricultural intensification including intercropping and the use of improved varietal technologies, among others.

Ensuring nutritionally adequate food supply requires, among others, adopting sustainable agricultural intensification (SAI) practices, especially in the face of expected population growth and climatic change (Haile et al., 2017). In turn, this necessitates the application of available options for intensification like intercropping and others. Broadly defined, SAI practices may include various inputs and practices such as prudent use of chemical fertilizers, improved crop cultivars, soil and water conservation, cereal-legume intercropping, crop rotation, and agroforestry. SAI aims to improve resource-use efficiency while producing more food from the same resources and enhancing beneficial environmental and social services (Pretty et al., 2011; Garnett et al., 2013; Smith et al., 2016). Intercropping is among the most 
important farming practices that would contribute to a sustainable agricultural intensification.

In Ethiopia, maize is the second most important cereal crop in terms of acreage next to tef and the first in terms of volume of production. In 2019, about 2.37 million hectares were allocated to maize production and about 9.50 metric tons were harvested (CSA, 2019). In terms of the use of improved varieties, maize takes the first rank among cereals. For instance, about $54.9 \%$ of the maize field in 2018 was covered by improved maize varieties (CSA, 2018). It is also among the crops that are often used in multiple cropping systems like intercropping practices. In the study area (East Hararghe zone), maize took the second rank both in terms of production and area coverage next to sorghum (CSA, 2016). Maize-common bean intercropping is also a very common practice in the zone, as compared to other areas in the country.

The importance of maize in the country's agricultural economy and household level food security calls for increasing its production and productivity through the use of modern technologies (Jaleta et al., 2013). Realizing the importance of maize in SAI practices and in the production system in general, the research system of the country has been committing human and financial resources for developing appropriate maize technologies and practices. The national maize research program was given the broad objective of developing cultivars and other improved practices suitable for major maize producing areas. Accordingly, maize breeding efforts have resulted in the release of many improved maize varieties together with their associated recommended packages and SAI practices. Studies indicate that maize is one of the major food crops where research brought tangible improvement in production and productivity (Jaleta et al., 2013). According to Jaleta et al. (2013), since the beginning of the 1970's, more than 40 improved maize varieties have been released and disseminated to maize potential areas in Ethiopia. In addition to many local cultivars, BH661 and BHQPY545 are among the recently released varieties that are being used in East Hararghe.

Intercropping maize with legumes reduces dependence on synthetic $\mathrm{N}$ fertilizers which have adverse economic and environmental consequences. Furthermore, the introduction of legumes has both economic and environmental advantages, especially when grain legumes achieve high prices as human food. Grain legumes fix atmospheric nitrogen gas $\left(\mathrm{N}_{2}\right)$ and can contribute to the $\mathrm{N}$ economy of fields, provide other rotational benefits to subsequent crops, produce in situ high-quality organic residues with high nitrogen $(\mathrm{N})$ concentration and low carbon (C) to nitrogen ratio, and thereby contribute to integrated soil fertility management (Srivastava et al., 2019). Many earlier studies have demonstrated that cereallegume mixtures are the most productive form of intercropping since the cereals may benefit from the nitrogen fixed in the root nodules of the legumes in the current year (Adu-Gyamfi et al., 2007) or in the subsequent years (Giller and Wilson, 1993). Furthermore, many studies have reported the positive impacts of cereal-legume intercropping on yield, income, and nutrition security (Mucheru et al., 2010; Rusinamhodzia et al., 2012), particularly in vulnerable production systems. Rusinamhodzia et al. (2012) indicated that intercropping cereals with legumes are a feasible entry point to ecological intensification. However, intercropping cannot be an end by itself. Per hectare yields and benefits from the component crops (maize and common bean, in this case) should be maximized as much as possible. This could be done by adopting high yielding improved varieties of the component crops.

Despite the growth in maize area coverage and considerable efforts in maize research, the mean national yield of about 39.92 Quintals per hectare is very small as compared to the global mean yield (CSA, 2019). This relatively low figure may be partially attributed to the low level of adoption of improved maize technologies and SAI practices. There exists an accumulated a wealth of literature on factors that are believed to contribute to the low level of adoption of technologies in general and improved maize varieties in particular. These factors generally include attributes related to the farm, the farmer, the technology, and the farming objectives. Jaleta et al. (2013) categorize these factors as either internal or external to the farmer's circumstances. According to this study, farmers' attitude towards risk, household characteristics related to production and consumption, and resource endowment could, among others, constitute the internal factors, while access to technologies, infrastructure, institutions, markets, and enabling policy environments are examples of external factors to the farmers. Several studies (e.g., Alene et al., 2000; Feleke and Zegeye, 2006; Jaleta et al., 2013; Legese et al., 2011; Tura et al., 2010-all in Ethiopia; Oluwayemisi et al., 2017 in West Africa; Kudi et al., 2011 in Nigeria; Kaliba et al., 2000 in Tanzania; Sánchez-Toledano, 2018 in Mexico) have analyzed the determinants of adoption of improved maize varieties.

However, the bulk of the adoption studies on improved varieties focused on sole cropping arrangements. Little attention has been given to assess factors affecting adoption under the intercropping system, especially cereallegume intercropping which is one of the most important components under the SAI practices. Hence, a more careful examination of the interaction between the characteristics of the technology and the characteristics of farmers and the farm under the intercropping system is required. If solutions are to be sought for the poor adoption of technologies, those solutions must emphasize the key factors contributing to the low level of adoption. This study, therefore, focused on assessing factors influencing the adoption of improved varieties of maize under the maize-common bean intercropping system of selected districts (woredas) in the East Hararghe zone of eastern Ethiopia. It also looked into differences in food and nutrition security of households between adopters and nonadopters of improved maize varieties.

\section{Materials and Methods}

\section{An Overview of the Study Area}

This study was undertaken based on data collected from two districts, Kombolcha and Meta, in East Hararghe zone of Eastern Ethiopia (Figure 1). Kombolcha district is one of the districts in East Hararghe zone of Oromia region. The topography of Kombolcha is a very complex terrain that includes gently sloping dissected plains and plateaus to moderately steep and undulating medium to high 
gradient hills. The approximate total area of the district is 30,452 ha, of which the largest portion (i.e. 78 percent) is covered by nonagricultural land. It receives a mean annual rainfall of $600-900 \mathrm{~mm}$, which is bimodal but erratic in distribution. The major crops grown in the district include sorghum, maize, fenugreek, linseed, common bean, and wheat in some high elevation areas, and groundnut in the lowlands. The main vegetable crops grown are tomato, beetroot, potato, cabbage, onion, carrot, pepper, lettuce, shallot, sweet potato, and spinach. Khat (Catha edulis), coffee, fruits, and vegetables are the main cash crops. Maize-common bean intercropping is practiced in the study areas.

Meta district is located in East Hararghe zone of Oromia region. The topography of the district ranges from nearly flat land to moderately steep land with the latter occupying the larger proportion of the total area. The dominant field crops grown include sorghum, maize, teff, wheat, barley, faba bean, field pea, common bean, and some oil crops (e.g., linseed). Maize-common bean intercropping is practiced in the district. Commonly grown horticultural crops include potato, onion, tomato, garlic, pepper, cabbage, and others. The district town is located on the main highway to Harar and Dire Dawa cities. As a result, areas that are closer to the high way have better access to market.

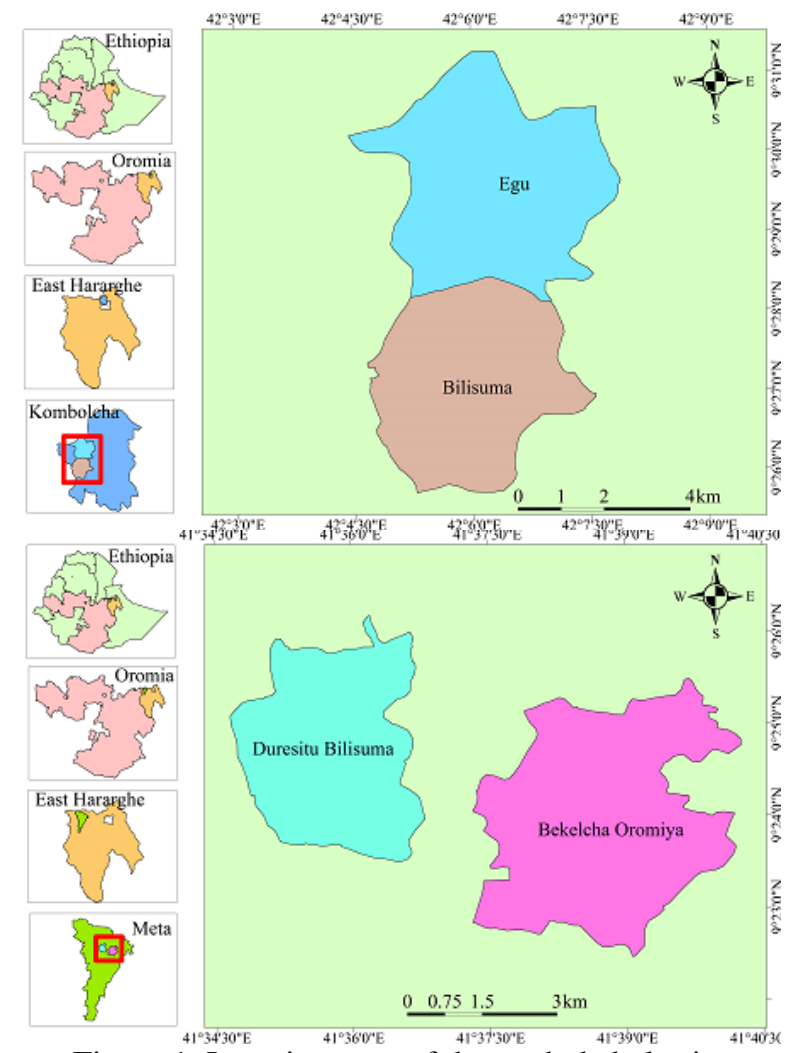

Figure 1. Location map of the study kebeles in Kombolcha (top) and Meta (bottom) districts.

\section{Sources and Methods of Data Collection}

Primary data were collected from a randomly selected households under the EU funded InnovAfrica (InnovAfrica (Innovations in Technology, Institutional and Extension Approaches towards Sustainable) Project being implemented in six African countries. In the case of Ethiopia, two districts in Eastern Ethiopia, Meta and
Kombolcha, are considered for project implementation as they are predominantly engaged in intensification though intercropping. Out of 615 households considered by the project in these two districts, this study utilized 129 households who are involved in maize-common bean intercropping practices. The number of adopters and nonadopters among the total sample was, therefore, probabilistically determined resulting into $32 \%$ adopters and $68 \%$ non-adopters.

\section{Selection of the Empirical Model}

Framers' decision to adopt a certain technology is affected by a set of factors. These include socio-economic, demographic, technological, and institutional factors. Theoretically, there are a set of techniques that enable one to examine the relationship between the farmers' adoption behavior and factors affecting it. The dependent variable (adoption status) is a dummy (dichotomous) variable taking a value of one for adopters of technologies and zero for non-adopters. Estimation of such a variable entails the use of binary choice models. In this regard, Logit model or Probit model can be applied.

Parameter estimates obtained from probit and logit models are similar and it is difficult to distinguish them statistically. Gujarati (2003) and Pindyck and Rubinfeld (1981) pointed out that the logistic and probit formulations are quite comparable, the chief difference being that the former has slightly flatter tails, that is, the probit curve approaches the axes more quickly than the logistic curve.

Therefore, the choice between logit and probit models is one of mathematical convenience and ready availability of computer programs. On this score, the logit model is generally used in preference to the probit (Gujarati, 2003). Consequently, because of the fact that the logit model is relatively simple from mathematical point of view and lends itself to a meaningful interpretation, it was used in the present study.

\section{Specification of the Logit Model}

The dependent variable is binary while the explanatory variables can either be continuous or binary.

The cumulative logistic probability function is specified as:

$$
\mathrm{P}_{\mathrm{i}}=\mathrm{F}\left(\mathrm{Z}_{\mathrm{i}}\right)=\mathrm{F}(\alpha)+\sum \beta_{\mathrm{t}} \mathrm{X}_{\mathrm{ti}}=\left(\frac{1}{1+\mathrm{e}^{-\left(\alpha+\sum \beta_{\mathrm{t}} \mathrm{X}_{\mathrm{ti}}\right)}}\right)
$$

Where;

e: represents the base of natural logarithms (2.718);

$\mathrm{X}_{\mathrm{ti}}$ : represents the $\mathrm{t}^{\text {th }}$ explanatory variable $(\mathrm{t}=1,2, \ldots, \mathrm{m})$ for the $\mathrm{i}^{\text {th }}$ individual;

$\mathrm{P}_{\mathrm{i}}$ : is the probability that $\mathrm{i}^{\text {th }}$ individual will make a certain choice (in this case adopt or do not adopt improved maize varieties) given $\mathrm{m}$ explanatory variables;

$\alpha$ and $\beta_{\mathrm{t}}$ : are parameters to be estimated $(\mathrm{t}=1,2, \ldots, \mathrm{m} ; \mathrm{m}$ is number of explanatory variables).

Interpretation of the coefficients will be understandable if the logistic model is written in terms of the odds and log of odds (Hosmer and Lemeshow, 1989). The odds ratio implies the ratio of the probability that an individual would choose an alternative $\left(\mathrm{P}_{\mathrm{i}}\right)$ to the probability that he/she would not choose it $\left(1-\mathrm{P}_{\mathrm{i}}\right)$. 
In terms of odds ratio, the logit model takes the following form:

$$
Z_{i}=\ln \left(\frac{P_{i}}{1-P_{i}}\right)=\alpha+\beta_{1} X_{1 i}+\beta_{2} X_{2 i}+\ldots+\beta_{m i} X_{m i}+U_{i}
$$

Hence, the above econometric model was used in this study and was treated against potential variables assumed to affect the adoption status of maize producing farmers in the maize-common bean intercropping system. The model was estimated using the iterative maximum likelihood estimation procedure which yields unbiased and asymptotically efficient and consistent parameter estimate.

\section{Definition of Variables and Working Hypotheses}

After specifying the analytical procedures, it is essential to identify and define the potential explanatory variables, describe their measurements, and formulate working hypotheses in relation to their effects on the dependent adoption variable already explained as dummy variable. Based on literature review, several factors have been hypothesized to affect the adoption status of the farming households. In what follows, a brief explanation of explanatory variables selected for this study and their effects on the adoption of improved maize varieties are presented.

Age of household head: This is the number of full years since the time of birth that the farm household head had completed at the time of the survey. A farmer's age can either generate or erode confidence in new technology. Older farmers may have more experience and resources that would allow them more possibilities for trying a new technology (Melese, 2018; Paudel et al., 2008). Others argue that older farmers could be conservative to adopt new technology (Ullah et al., 2018; Emmanuel et al., 2016; Abdulai and Huffman, 2014). On the contrary, younger farmers are more likely to adopt a new technology, because they have had more schooling than the older generation or perhaps have been exposed to new ideas (Melese, 2018) or have positive attitudes towards innovation and with low risk perception (Sánchez-Toledano et al., 2018). Yet, other studies (e.g., Freud et al., 1996) indicated that farmers' age and adoption of modern technologies are not at all related. Hence, the effect of age on adoption of maize technology is indeterminate.

Literacy: Defined as a dummy variable takes a value of one (1) for literates and zero for illiterates. Exposure to education should increase farmers' ability to obtain, process, and use information relevant to the adoption of improved maize varieties (Aydogdu and Yenigün, 2016; Shiferaw et al., 2014; Lavison, 2013; Mignouna et al., 2011). Education improves the skill and entrepreneurial ability of the decision-makers and creates opportunities to improve managerial ability of farmers (Nyuor et al., 2016). Educated farmers could be more receptive to advice from an extension agency and from other sources of information. They could also be able to deal with technical recommendations that require a certain level of numeracy or literacy. When summarized, technology adoption increases if farmers are more educated (Mariano et al., 2012). Education is, thus, thought to increase the probability that a farmer will adopt improved maize varieties.
Use of credit: This is a dummy variable which takes a value of one if the household received credit for the season and zero otherwise. Credit can relax financial constraints of farmers since it helps them in acquiring basic agricultural inputs, such as labor, fertilizers, seed and herbicides (Nyuor et al., 2016; Kafle, 2011). Especially when a recommendation implies a significant cash investment for farmers, adoption of that recommendation may be facilitated by an efficient credit program (Ogada et al., 2014). Therefore, with the availability of necessary credit, farmers are able to purchase productive farm inputs and invest in the technology (Melese, 2018; Ullah et al., 2018; Abdualai et al., 2011). In general, farmers who are resource endowed will have a higher inclination towards adoption of a technology (Martey et al., 2014). In this study, it was expected or assumed that access to credit would increase the probability of adopting improved maize varieties.

Tropical Livestock Unit (TLU): The number of livestock owned by farmers was hypothesized to positively affect adoption of improved maize varieties. Heyi and Mberengwa (2012) used livestock ownership status as a proxy for availability of household resource endowment. Dhraief et al. (2018) also hypothesized that livestock owners with a high flock size have a higher propensity to adopt innovative technologies than the small livestock owners. The number of livestock owned is taken, in this study, as an index called Tropical Livestock Unit (TLU) using a standard conversion factors for different livestock categories.

Landholding size: This is measured in hectares. On the relationship between landholding and adoption of technologies, there are two opposite thoughts. The first one is that farm size is an indicator of wealth and perhaps a proxy for social status. Large-scale farmers will be more likely to adopt a technology (Mignouna et al., 2011), especially if the innovation requires an extra cash investment in which case the relationship is positive. The second thought, on the other hand, justifies negative relationship between landholding size and adoption of technologies (Harper et al., 1990). Accordingly, smallholder farmers utilize the limited resources more efficiently and adopt new technologies at a faster rate.

Distance to road: This is measured in kilometers. Distance to the main road was hypothesized to be negatively related to the probability of adopting improved maize varieties. This is because of the fact that households near to the main road (and hence to a market) tend to use improved maize varieties, for they can have easy access to sell their products on the one hand and timely purchase the required inputs on the other. Many empirical studies (e.g., Bayissa, 2014; Gebresilassie and Bekele, 2015; Shita et al., 2018) have reported negative relationship between distance to road (market) and adoption of technology.

Frequency of extension contact: This is the number of annual contacts of the household head with extension agents. Extension services provided by the ministry of agriculture are the major sources of agricultural information in the study area. Akudugu et al. (2012) indicated that access to extension services can counteract the negative effect of lack of formal education of farmers which hinders technology adoption. In developing countries, there is a general belief that extension agents 
usually select a particular contact farmer who is recognized as the most influential agent to deliver new technology (Silva and Broekel, 2016). Studies have reported a positive relationship between extension services and technology adoption (Mignouna et al., 2011; Mwangi and Kariuki, 2015). It was hypothesized that frequency of contact with extension workers will increase farmers' likelihood of adopting improved maize varieties.

Membership in formal organizations: This is a dummy variable which takes a value of one if the household head is a member of organizations like coops and farmers' group and zero otherwise. Being a member of organization puts a farmer in a privileged position in relation to other farmers. This is because, members of an organization have better access to technical information and receive preferential treatment from extension workers. Katungi and Akankwasa (2010) found that farmers who participated more in community-based organizations were likely to engage in social learning about the technology hence raising their likelihood to adopt the technologies. Membership is, therefore, hypothesized to be positively associated with the adoption of improved maize varieties.

Sex of the household head: This is a dummy variable taking a value of one if the household head is male and zero otherwise. Male and female heads can have different adoption rates. This variable can be positive or negative. Large number of studies have analyzed the influence of gender on farmers' technology adoption behavior (Abdulai and Huffman, 2014; Abdulai et al., 2011; Gebregziabher et al., 2014; Mariano et al., 2012; Oluwayemisi et al., 2017).

District dummy: This is a dummy variable for taking into account variations in geographical location. It takes a value of one for Komolcha District and zero for Meta District.

Number of plots: It is the number of farm plots owned by the households. It is used as a proxy for land fragmentation. Sun and $\mathrm{Li}$ (2010) defined land fragmentation as the presence of separate number of plots owned by the same owner at different places. Some recent studies (e.g., Kousar et al., 2020; Olarinre and Omonona, 2018) have considered fragmentation as a factor that affects different aspects of production and productivity. According to Latruffe and Piet (2014), land fragmentation is caused by many factors, such as social, political, institutional, and historical factors. The results of different studies reveal that land fragmentation can have both positive and negative effects on agricultural productivity and efficiency through its effects on performance of farmlands (Tan et al, 2010), the technical efficiency of farmers (Rahman and Rahman, 2008), cost and benefit of the farmlands (Olarinre and Omonona, 2018), and profitability of the farmers (Di Falco et al., 2010).

\section{Results and Discussion}

\section{Household Characteristics}

Average age of adopter household heads was about 43 years while that of non-adopters was 38 years. This difference is statistically significant at $5 \%$ level. This result indicates that older farmers are better adopters of the technology as compared to the young farmers. Furthermore, adopter household heads had more years of schooling than that of the non-adopter household heads. Similarly, more illiterate household heads are available in the non-adopter categories (Table 1). Kariyasa and Dewi (2011) believe that older farmers are assumed to have gained knowledge and experience over time and are better able to evaluate technology information than younger farmers are. If age of a household is equated to farming experience, Ullah et al. (2018) argue that farmers who are more experienced have greater ability to process information and search for technologies suitable to their production constraints albeit other studies (e.g., Oluwayemisi et al., 2017) claim the opposite. With regard to education, Nyuor et al. (2016) assert that education increases the managerial ability of farmers. Mariano et al. (2012) strongly believes that technology adoption rate increases if farmers are more educated (Mariano et al., 2012). Similarly, Mignouna et al. (2011) claim that education level of a farmer determines his/her ability to obtain, process and use information relevant to the adoption of a new technology in a positive way.

Table 1. Household characteristics by adoption status

\begin{tabular}{|c|c|c|c|c|c|c|c|c|}
\hline \multirow{2}{*}{\multicolumn{2}{|c|}{ Characteristics }} & \multicolumn{2}{|c|}{ Adopters } & \multicolumn{2}{|c|}{ Non-adopters } & \multicolumn{2}{|c|}{ Total } & \multirow{2}{*}{$\chi^{2}$-value } \\
\hline & & no. & $\%$ & no. & $\%$ & no. & $\%$ & \\
\hline \multirow{2}{*}{ Sex of the head } & Male & 40 & 33.9 & 78 & 66.1 & 118 & 91.5 & \multirow{2}{*}{$2.856^{*}$} \\
\hline & Female & 1 & 9.1 & 10 & 90.9 & 11 & 8.5 & \\
\hline \multirow{3}{*}{ Education } & Literate & 30 & 36.6 & 52 & 63.4 & 82 & 63.6 & \multirow{2}{*}{2.394} \\
\hline & Illiterate & 11 & 23.4 & 36 & 76.6 & 47 & 36.4 & \\
\hline & & mean & SD & mean & SD & mean & SD & t-value \\
\hline \multirow{2}{*}{\multicolumn{2}{|c|}{$\begin{array}{l}\text { Age of the household head (years) } \\
\text { Years of schooling of the head }\end{array}$}} & 42.9 & 10.41 & 38.1 & 9.66 & 39.6 & 10.11 & $-2.55 * *$ \\
\hline & & 4.44 & 3.59 & 3.65 & 3.69 & 3.90 & 3.66 & -1.44 \\
\hline
\end{tabular}

Note: **, and * indicate significance at $5 \%$ and $10 \%$ levels respectively; SD = Standard Deviation.

\section{Institutional Characteristics}

More of those households who had no extension contact fall in the non-adopters' category. This difference is statistically significant. This is expected since access to extension services plays a decisive role in the dissemination of useful and practical information related to agricultural technology adoption (Pan, 2014). It is also viewed as one key means of offsetting the negative effect of lack of formal education of farmers, which most of the time hinders technology adoption (Akudugu et al., 2012). Cognizant of this, Mwangi and Kriuki (2015) described availability and access to extension services as a key aspect in agricultural technology adoption. The differences between adopters and non-adopters in terms of access to credit, memberships to groups/associations, distance to market and to main road were not statistically significant (Table 2). Cooperatives and farmers' group are some of the organizations to which farmers belong. 


\section{Food and Nutrition Security}

The dietary diversity scores (DDS) were computed based on the number of food item groups the households consumed within 24 hours. The scores have been calculated based on the 12 food groups, namely, cereals; root and tubers; vegetables; fruits; meat, poultry, and offal; eggs; fish and sea food; pulses/legumes/nuts; milk and milk products; oil/fats; sugar/honey; and miscellaneous. Those that consumed three or less number of the food item groups were categorized as low DDS, four and five as medium DDS, and six and above as high DDS. The average DDS value for consuming major food groups was 5.72 implying that households were consuming about six food groups in general. The figures are 6.15 for adopters and 5.52 for non-adopters of improved maize varieties in maize-common bean intercropping system. The difference is statistically significant at $10 \%$. This implies the fact that adopters are in a better position in terms of nutrition security. In terms of DDS categories, $82.4 \%$ of those who fall under low DDS levels were non-adopters while the remaining $17.6 \%$ were adopters, though the difference in DDS score between the two groups was not statistically significant. Furthermore, about $68 \%$ of those who reported facing food shortage were non-adopters of improved maize varieties while the remaining $32 \%$ were adopters (Table 3 ). Relatively speaking, it can be deduced that adopters had better levels of food and nutrition security. In line with this, Dawson et al. (2018) and Fung et al. (2019) also indicated the fact that agricultural intensification and intercropping, respectively, improve food security situation. Rusinamhodzia et al. (2012) concluded that intercropping cereals with legumes improves income and nutrition security. The same study confirmed that maize-legume intercropping is a feasible entry point to ecological intensification since it has the potential to reduce the risk of crop failure, improve productivity and income, and increase food security in vulnerable production systems.

Table 2. Institutional characteristics of household heads by adoption status

\begin{tabular}{|c|c|c|c|c|c|c|c|c|}
\hline \multirow{2}{*}{\multicolumn{2}{|c|}{ Characteristics }} & \multicolumn{2}{|c|}{ Adopters } & \multicolumn{2}{|c|}{ Non-adopters } & \multicolumn{2}{|c|}{ Total } & \multirow{2}{*}{$\chi^{2}$-value } \\
\hline & & no. & $\%$ & no. & $\%$ & no. & $\%$ & \\
\hline \multirow{2}{*}{ Extension contact } & Yes & 11 & 45.8 & 13 & 54.2 & 24 & 18.6 & \multirow{2}{*}{$2.67 *$} \\
\hline & No & 30 & 28.6 & 75 & 71.4 & 105 & 81.4 & \\
\hline \multirow{2}{*}{ Access to credit } & Yes & 16 & 38.1 & 26 & 61.9 & 42 & 32.6 & \multirow{2}{*}{0.285} \\
\hline & No & 25 & 28.7 & 62 & 71.3 & 87 & 67.4 & \\
\hline Membership to & Yes & 3 & 60 & 2 & 40 & 5 & 3.9 & \multirow{2}{*}{1.91} \\
\hline \multirow[t]{2}{*}{ group/association } & No & 38 & 30.6 & 86 & 69.4 & 124 & 96.1 & \\
\hline & & mean & SD & mean & SD & mean & SD & $\mathrm{t}$-value \\
\hline \multicolumn{2}{|c|}{ Market distance $(\mathrm{km})$} & 5.54 & 1.6 & 5.70 & 2.26 & 5.65 & 2.07 & 0.468 \\
\hline \multicolumn{2}{|c|}{ Distance to main road $(\mathrm{km})$} & 1.60 & 1.42 & 204 & 1.54 & 1.90 & 1.51 & 1.543 \\
\hline
\end{tabular}

Note: * indicates significance at $10 \%$ level; SD = Standard Deviation.

Table 3. Food and nutrition security by adoption status

\begin{tabular}{ll|ccccccc}
\multicolumn{2}{c}{ Characteristics } & \multicolumn{2}{c}{ Adopters } & \multicolumn{2}{c}{ Non-adopters } & \multicolumn{2}{c}{ Total } & \multirow{2}{*}{$\chi^{2}$-value } \\
\cline { 3 - 7 } & & no. & $\%$ & no. & $\%$ & no. & $\%$ & \\
\multirow{2}{*}{ Food shortage faced } & Yes & 38 & 31.9 & 82 & 68.3 & 120 & 93 & \multirow{2}{*}{0.011} \\
& No & 3 & 33.3 & 6 & 66.7 & 9 & 7 & \\
\multirow{2}{*}{ Dietary Diversity } & Low & 3 & 17.6 & 14 & 82.4 & 17 & 13.2 & \\
Score & Medium & 8 & 23.5 & 26 & 76.5 & 34 & 26.4 & 4.24 \\
& High & 30 & 38.5 & 48 & 61.5 & 78 & 60.5 & \\
\hline
\end{tabular}

\section{Income and Resource Ownership}

The average cultivated land owned by the sample households was about 0.4 ha. There was no statistically significant difference between adopters and non-adopters in terms of land size (Table 4). Land is one of the scarce factors of production whose supply is fixed. Land size owned by the farm households may determine adoption of improved seeds, use of inputs, and investment in land improvements. In terms of the number of parcels (plots) owned by household heads, adopters had about three plots while non-adopters operate on about two plots. This difference between the two groups is statistically significant.

The average livestock holding in Tropical Livestock Unit (TLU) was 1.81 for adopters and 1.64 for nonadopters. Livestock are important assets for rural households and serve different purposes. Cattle provide draft power for crop cultivation, manure for household fuel and organic fertilizer, meat and milk for consumption, and other products like hides and skins. Pack animals are used for transporting loads and human beings. Small ruminants are used to meet immediate cash demand of the households and also for meat production for household consumption especially during holidays. Poultry are kept for egg and meat production both for cash and home consumption. Livestock are also considered as indicators of wealth and prestige in rural areas. However, the difference between adopters and non-adopters in terms of TLU was not statistically significant. In terms of annual farm income, households obtain about USD 1149 and there was no statistically significant difference between adopters and non-adopters (Table 4). 
Factors Affecting Adoption of Improved Maize Varieties

Eleven variables were hypothesized to affect adoption of improved maize varieties in a maize-common-bean intercropping system. Descriptive values of these variables are as indicated in Table 5 below.

The logistic regression model was estimated so as to determine factors that are influencing the adoption of improved maize varieties. The parameters included in the model taken together are significantly different from zero as evidenced by the significance of Chi-square value $(\mathrm{P}<0.01)$. Another measure of goodness of fit is based on a scheme that classifies the predicted value of adoption status as one or zero based on a cut-point probability of 0.5 (i.e. if $\mathrm{Pi} \geq 0.5$, then the value of adoption status is one, and zero otherwise). Accordingly, the model correctly predicted about $75.2 \%$ of the observations. The signs of all the coefficients more or less turned out to be consistent with the a priori expectations. The maximum likelihood estimates of the logistic regression model are presented in Table 6 below.

Out of the 11 explanatory variables hypothesized to affect adoption status, five were found to be statistically significant at different probability levels. These are district (location) dummy, education status of the household head, age of the household head, distance to main road, and number of plots owned by households.

As expected, education status of the household head had positive and significant effect on the adoption of improved maize varieties. Literate households had $431 \%$ (more than 4 times) higher odds of adopting improved maize varieties as compared to the illiterates. This result is in line with that of Haile et al. (2017) who reported that average education of the household positively affected adoption intensity of sustainable intensification practices. Many other studies conducted in different countries [e.g., Oluwayemisi et al., 2017 (West Africa); Jaleta et al., 2013 (Ethiopia); Kudi et al., 2011 (Nigeria); Alene et al. 2000 (Ethiopia); Kaliba et al., 2000 (Tanzania)] reported education affects technology adoption positively and significantly. This is because of the fact that education enables farmers to obtain and analyze relevant farm information from different sources for adopting improved maize technologies. This implies that educating farmers would improve technology adoption and increase crop productivity and thereby improve food security situation.

Table 4. Income and resource ownership by adoption status

\begin{tabular}{l|rrrrrrr}
\multirow{2}{*}{\multicolumn{1}{c}{ Characteristics }} & \multicolumn{2}{c}{ Adopters } & \multicolumn{2}{c}{ Non-adopters } & \multicolumn{2}{c}{ Total } & \multirow{2}{*}{ t-value } \\
\cline { 2 - 7 } & mean & SD & mean & SD & mean & SD & -0.173 \\
Land ownership (ha) & 0.391 & 0.194 & 0.381 & 0.340 & 0.384 & 0.301 & $-2.012 * *$ \\
Number of plots owned & 2.71 & 0.844 & 2.35 & 0.971 & 2.47 & 0.944 & -0.524 \\
Livestock ownership (TLU) & 1.81 & 1.226 & 1.64 & 1.882 & 1.69 & 1.698 & 0.552 \\
Annual farm income (USD) & 1051.5 & 664.1 & 1195.0 & 1599.1 & 1148.7 & 1367.3 & 0.7 \\
\hline
\end{tabular}

Note: ** indicates significance at $5 \%$ level of significance; SD = Standard Deviation.

Table 5. Descriptive statistics of the explanatory variables

\begin{tabular}{|c|c|c|c|}
\hline Variable & Unit or type & $\%$ with a value one & Mean \\
\hline District (Meta) & Dummy & 52.7 & \\
\hline Sex of the head (Male) & Dummy & 91.5 & \\
\hline Education (literate) & Dummy & 63.6 & \\
\hline Extension contact (accessed) & Dummy & 18.6 & \\
\hline Credit (borrowed) & Dummy & 32.6 & \\
\hline Group membership (members) & Dummy & 3.9 & \\
\hline Age of the household head & years & & 39.60 \\
\hline Distance to road & $\mathrm{km}$ & & 1.90 \\
\hline Land holding & $\mathrm{Ha}$ & & 0.38 \\
\hline Number of plots & number & & 2.47 \\
\hline Livestock holding & TLU & & 1.69 \\
\hline
\end{tabular}

Table 6. Parameter estimates of the logistic regression model

\begin{tabular}{l|ccc}
\hline Explanatory variables & Estimated coefficients & Standard error & Odds ratio \\
\hline District & $-2.010^{* * * * 134}$ \\
Sex of the head & 1.519 & 0.542 & 4.567 \\
Education & $1.670^{* * *}$ & 1.197 & 5.314 \\
Extension contact & 0.391 & 0.609 & 1.478 \\
Credit & -0.187 & 0.662 & 0.829 \\
Group membership & 0.708 & 0.533 & 2.029 \\
Age of the household head & $0.067 * * *$ & 1.292 & 1.069 \\
Distance to road & $-0.290^{*}$ & 0.025 & 0.748 \\
Land holding & -1.714 & 0.168 & 0.180 \\
Number of plots & $0.760^{* *}$ & 1.462 & 2.138 \\
Livestock holding & 0.079 & 0.325 & 1.083 \\
Constant & $-6.198^{* * *}$ & 0.126 & 0.002 \\
Percent Correctly Predicted & 75.19 & 1.921 & \\
Chi-square value & $41.78^{* * *}$ & & \\
Note: $* * *, *$ and $*$ indicate significance at $1 \%, 5 \%$, and $10 \%$ levels respectively. & \\
\hline
\end{tabular}


The results of this study also indicated the fact that having a greater number of farm plots increases adoption of improved maize varieties in the maize-common bean intercropping system. As the number of plots increases by one, the odds of adopting improved maize variety increases by about $114 \%$. This is related to the risk spreading benefit of having more plots as compared to lesser number of plots. Having a greater number of plots spread production risks over space/location as production failure may not simultaneously happen in all the plots owned by the farm households. This in turn increases confidence of producers to adopt improved varieties and to make other farm investments on the plots. In consent with the current result, Bjibo and Maman (2019), in their study in Niger, reported increase in adoption of plant protection products with increase in plot number.

As expected, distance to the main road negatively and significantly affected adoption of improved maize varieties. As distance increases by one kilometer, the odds of adopting improved varieties decreases by $75 \%$. As distance to main road increases, the drudgery of getting access to product market and to input market increases, which in turn discourages farmers to adopt improved maize varieties because of lesser market incentives. Households that are nearer to the main road would also get better access to market information. This implies the need to expand road infrastructure for improving producers' access to market and information. The influence of distance particularly to market on technology adoption was also reported by many studies (Shita et al., 2018; Berihun et al., 2014; Beshir et al., 2012).

The result also indicated that age of the household head positively and significantly increased adoption of improved maize varieties. As age increases by one year, the odds of adopting improved maize variety increases by about $6.9 \%$. Age can be taken as a proxy for farming experience. Hence, as age increases farmers would accumulate experiences about benefit improving technologies, practices, and investments. In line with this, Oluwayemisi et al. (2017) for West Africa and Kaliba et al. (2000) for Tanzania reported the positive effect of age on adoption of improved maize varieties. Contrary to these reports and our finding, Sánchez-Toledano et al. (2018) for Mexico, Jaleta et al. (2013) and Alene et al. (2000) found age as a factor that negatively affects improved maize varieties' adoption. The current result calls for the need to have experience sharing events among farmers of different age groups in the study areas.

In terms of location, farmers in Kombolcha district had less propensity to adopt improved maize varieties in the maize-common bean intercropping. The odds of adopting improved maize varieties of farmers in Kombolcha district is $13.4 \%$ lesser than those in Meta district. Better adoption status of farmers in Meta district might be related to the location advantage that the farmers in the district could get in terms of accessing market and information. Studies in the past have confirmed the importance of distance to market in technology adoption (Admassie and Ayele, 2010; Ullah et al., 2018).

\section{Conclusions and Recommendations}

The effect of several factors on adoption decision of farmers on maize varieties in the maize-common bean intercropping system was examined using the logistic regression model. The results of the study revealed that adoption decision for improved maize varieties in maizecommon bean intercropping system is influenced by education status of the household head, age of the household head, distance to main road, number of plots owned, and location/district.

According to the results of this study, literacy, age of the household head, and number of plots owned positively affected the probability of adopting, while distance to main road negatively affected the probability of adopting improved maize varieties in the maize-common bean intercropping. Furthermore, descriptive results indicated the fact that adopters of improved maize varieties in the SAI practices are in a better position in terms of food and nutrition security.

Access to product and input market and to information through accessing main road is crucially important in facilitating the adoption process. Hence, improving rural road infrastructure can be taken among important strategies for boasting technology adoption.

The fact that education improves adoption requires giving due attention to educating and training farmers. This could be achieved through expansion of adult education and offering tailored training in the farmers' training centers besides expansion of the formal education. Furthermore, it is necessary to organize experience sharing events among farmers of different age groups focusing on the benefits of adopting improved maize varieties in the SAI practices.

Due attention should also be given to raising awareness among farmers about the food and nutrition benefits of adopting improved varieties of component crops in the intercropping practices as part of the SAI practices.

\section{Acknowledgements}

The authors are very thankful to the EU as this research work is based on EU-funded InnovAfrica project.

\section{References}

Abdulai A, Huffman W. 2014. The adoption and impact of soil and water conservation technology: an endogenous switching regression application. Land Economics, 90 (1): 26-43.

Abdulai A, Owusu V, Bakang JEA. 2011. Adoption of safer irrigation technologies and cropping patterns: evidence from southern Ghana. Ecological Economics, 70 (7): 1415-1423. DOI: 10.1016/j.ecolecon.2011.03.004.

Admassie A, Ayele G. 2010. Adoption of improved technology in Ethiopia. Ethiopian Journal of Economics, 19(1): 155-180.

Adu-Gyamfi JJ, Myaka FA, Sakala WD, Odgaard R, Vesterager JM, Hogh-Jensen H. 2007. Biological nitrogen fixation and nitrogen and phosphorus budgets in farmer-managed intercrops of maize-pigeonpea in semi-arid Southern and Eastern Africa. Plant and Soil, 295: 127-136. DOI: https://doi.org/10.1007/s11104-007-9270-0.

Akudugu M, Guo E, Dadzie S. 2012. Adoption of modern agricultural production technologies by farm households in Ghana: What factors influence their decisions? Journal of Biology, Agriculture and Healthcare, 2(3). 
Alene AD, Poonyth D, Hassan RM. 2000. Determinants of adoption and intensity of use of improved maize varieties in the Central Highlands of Ethiopia: A Tobit analysis. Agrekon, 39 (4): 633-643. DOI: https://doi.org/10.1080/ 03031853.2000 .9523679$.

Aydogdu M, Yenigün K. 2016. Farmers' risk perception towards climate change: a case of the gap-şanliurfa region, Turkey. Sustainability, 8 (8): 806. DOI: $10.3390 / \mathrm{su} 8080806$.

Bayissa G. 2014. A Double-Hurdle approach to modelling of improved teff technologies adoption and intensity use in case of Diga District of East Wollega Zone. Global Journal of Environmental Research, 8: 41-49. DOI: 10.5829/ idosi.gjer.2014.8.3.1106.

Berihun K, Bihon K, Kibrom A. 2014. Adoption and Impact of Agricultural Technologies on Farm Income: Evidence from Southern Tigray, Northern Ethiopia. International Journal of Food and Agricultural Economics, 2(4): 91-106. DOI: 10.22004/ag.econ.190816.

Beshir H, Emana B, Kassa B, Jema Haji J. 2012. Determinants of chemical fertilizer technology adoption in North eastern highlands of Ethiopia: the double hurdle approach. Journal of Research in Economics and International Finance, 1(2): 3949.

Bybee-Finley, KA, Ryan MR. 2019. Advancing Intercropping Research and Practices in Industrialized Agricultural Landscapes. Agriculture, 8 (6): 80. DOI: 10.3390/ agriculture8060080.

CSA. 2017. Agricultural Sample Survey 2015/2016, Volume I, Report on Area and Production of Major Crops (Private Peasant Holdings), Meher season. Addis Ababa, Ethiopia.

CSA. 2018. Agricultural Sample Survey 2016 /17: Report on Farm Management Practices (Private Peasant Holdings, Meher Season), volume III, Addis Ababa, Ethiopia.

CSA. 2019. Agricultural Sample Survey 2018/19: Report on Area and Production of Major Crops (Private Peasant Holdings, Meher Season), Volume I, Addis Ababa, Ethiopia.

Dawson N, Martin A, Camfield L. 2018. Can agricultural intensification help attain sustainable development goals? Evidence from Africa and Asia. Third World Quarterly, 40 (5): 926-946. DOI: 10.1080/01436597.2019.1568190.

Dhraief, MZ, Bedhiaf-Romdhania S, Dhehibib B, OueslatiZlaouia M, Jebali O, Ben Youssef S. 2018. Factors Affecting the Adoption of Innovative Technologies by Livestock Farmers in Arid Area of Tunisia. FARA Research Report. Volume 3 (5): 22. DOI: 10.13140/RG.2.2.15795.27686.

Di Falco S, Penov I, Aleksiev A, van Rensburg T. 2010. Agrobiodiversity, farm profits and land fragmentation: Evidence from Bulgaria. Land Use Policy, 27: 763-771. DOI: 10.1016/j.landusepol.2009.10.007.

Djibo O, Maman NM. 2018. Determinants of agricultural technology adoption: Farm household's evidence from Niger. Journal of Development and Agricultural Economics, 11(1): 15-23. DOI: 10.5897/JDAE2018.0998.

Emmanuel D, Owusu-Sekyere E, Owusu V, Jordaan H. 2016. Impact of agricultural extension service on adoption of chemical fertilizer: Implications for rice productivity and development in Ghana. NJAS-Wageningen Journal of Life Sciences, 79: 41-49. DOI: https://doi.org/10.1016/ j.njas.2016.10.002.

Feleke S, Zegeye T. 2006. Adoption of improved maize varieties in Southern Ethiopia: Factors and strategy options. Food Policy, 31 (5): 442-457. DOI: 10.1016/j.foodpol 2005.12.003.

Freud EH, Phillipe P, Jacques R. 1996. Innovation in West African smallholder Cocoa: Some conventional and nonconventional measures of success. In: Food Security and Innovations: Successes and Lessons Learned, International Symposium, 131-146, Hohenheim, Germany.
Fung KM, Tai APK, Yong T, Liu X, Lam HM. 2019. Co-benefits of intercropping as a sustainable farming method for safeguarding both food security and air quality. Environmental Research Letters, 14. DOI: https://doi.org/ 10.1088/1748-9326/aafc8b.

Garnett T, Appleby MC, Balmford A, Bateman IJ, Benton TG, Bloomer P, Burlingame B, Dawkins M, Dolan L, Frasser D, Herrero M, Hoffmann I, Smith P, Thornton PK, Toulmin C, Vermeulen SJ, Godfray HCJ. 2013. Sustainable Intensification in Agriculture: Premises and Policies. Science, 341 (6141): 33-34. DOI: 10.1126/science. 1234485.

Gebregziabher G, Giordano M, Langan J, Namara R. 2014. Economic Analysis of Factors Influencing Adoption of Motor Pumps in Ethiopia. Journal of Development and Agricultural Economics, 6(12): 490-500. DOI: http://dx.doi.org/10.5897/ JDAE2014.0576.

Gebresilassie L, Bekele A. 2015. Factors determining allocation of land for improved wheat variety by smallholder farmers of northern Ethiopia. Journal of Development and Agricultural Economics, 7: 105-112. DOI: 10.5897/JDAE2014.0621.

Giller KE, Wilson KJ. 1993. Nitrogen Fixation in Tropical Cropping Systems CAB International, Wallingford, USA. DOI: 10.1079/9780851994178.0000.

Gujaratti D. 2003. Basic Econometrics. $4^{\text {rd }}$ edition, McGraw-Hill, Inc. New York. ISBN: 978-0071333450.

Haile B, Carlo CC, Koo AJ. 2017. Adoption of Sustainable Intensification Practices Evidence from Maize-legume Farming Systems in Tanzania. Environment and Production Technology Division, IFPRI Discussion Paper 01696.

Harper J, Rister M, Mjelde J, Drees M, Way M. 1990. Factors influencing the adoption of insect management technology. American Journal of Agricultural Economics, 72(4): 9971005. DOI: https://doi.org/10.2307/1242631.

Heyi DD, Mberengwa I. 2012. Determinants of farmers' land management practices: The Case of Tole District, South West Shewa Zone, Oromia National Regional State, Ethiopia. Journal of Sustainable Development in Africa, 14(1).

Hosmer DW, Lemeshew S. 1989. Applied Logistic Regression. A Wiley-Inter Science Publication, New York. DOI: https://doi.org/10.1002/sim.4780100718.

Jaleta M, Yirga C, Kassie M, de Groote H, Shiferaw B. 2013. Knowledge, adoption and use intensity of improved maize technologies in Ethiopia. Invited paper presented at the 4th International Conference of the African Association of Agricultural Economists, September 22-25, 2013, Hammamet, Tunisia.

Kafle B. 2011. Factors affecting adoption of organic vegetable farming in Chitwan District, Nepal. World Journal of Agricultural Sciences, 7: 604-606.

Kaliba ARM, Verkuij H, Mwangi W. 2000. Factors affecting adoption of improved maize seeds and use of inorganic fertilizer for maize production in the intermediate and lowland zones of Tanzania. Journal of Agricultural and Applied Economics, 32 (1): 35-47. DOI: https://doi.org/ $10.1017 /$ S 1074070800027802

Kariyasa K, Dewi A. 2011. Analysis of factors affecting adoption of integrated crop management farmer field school (Icm-Ffs) in swampy areas. International Journal of Food and Agricultural Economics, 1(2): 29-38.

Kousar R, Sohail M, Makhdum A, Ullah R, Saghir A, Usman S, Sadaf T. 2020. Empirical Investigation of Impact of Land Fragmentation on Crop Productivity in Punjab, Pakistan. Sarhad Journal of Agriculture, 36(1): 217-223. DOI: http://dx.doi.org/10.17582/journal.sja/2020/36.1.217.223.

Kudi TM, Bolaji M, Akinola MO, Nasa'I DH. 2011. Analysis of adoption of improved maize varieties among farmers in Kwara State, Nigeria. International Journal of Peace and Development Studies, 1(3): 8-12. 
Latruffe L, L Piet. 2014. Does land fragmentation affect farm performance? A case study from Brittany, France. Agricultural Systems, 129(1): 68-80. DOI: https://doi.org/ 10.1016/j.agsy.2014.05.005

Legese G, Langyintuo AS, Mwangi W, Jaleta M. 2011. Determinants of adoption of improved drought tolerant maize varieties and their implication for household food security in drought prone areas. Ethiopian Journal of Agricultural Economics, 8(1): 105-132.

Mariano MJ, Villano R, Fleming E. 2012. Factors influencing farmers' adoption of modern rice technologies and good management practices in the Philippines. Agricultural Systems, 110: 41-53. DOI: 10.1016/j.agsy.2012.03.010.

Martey E, Wiredu AN, Etwire PM, Fosu M, Buah SSJ, Bidzakin J, Ahiabor BDK, Kusi F. 2014. Fertilizer adoption and use intensity among smallholder farmers in northern Ghana: a case study of the AGRA soil health project. Sustainable Agriculture Research, 3 (1): 24-36. DOI:10.5539/sar.v3n1p24.

Melesse B. 2018. A Review on Factors Affecting Adoption of Agricultural New Technologies in Ethiopia. Journal of Agricultural Science and Food Research, 9: 226.

Mignouna B, Manyong M, Rusike J, Mutabazi S, Senkondo M. 2011. Determinants of adopting imazapyr-resistant maize technology and its impact on household income in Western Kenya: AgBioforum, 14(3), 158-163.

Mucheru MM, Pypers P, Mugendi D, Mugwe J, Merckx R, Vanlauwe B. 2010. A staggered maize-legume intercrop arrangement robustly increases crop yields and economic returns in the highlands of Central Kenya. Field Crops Research, 115 (2): 132-139. DOI: 10.1016/j.fcr.2009.10.013.

Mwangi M, Kariuki S. 2015. Factors determining adoption of new agricultural technology by smallholder farmers in developing countries. Journal of Economics and Sustainable Development, 6 (5): 201.

NBE (National Bank of Ethiopia). 2019. Annual Report of the National Bank of Ethiopia for the year 2018/19. Addis Ababa, Ethiopia. Available from: https://nbebank.com/annual-report/ [Accessed: 13.04.2020].

Nyuor, AB. 2016. Economic impacts of climate change on cereal production: Implications for sustainable agriculture in northern Ghana. Sustainability, 8 (8): 724. DOI: https://doi.org/ 10.3390/su8080724.

Ogada MJ, Mwabu G, Muchai D. 2014. Farm technology adoption in Kenya: a simultaneous estimation of inorganic fertilizer and improved maize variety adoption decisions. Agricultural and Food Economics, 2: 12. DOI: https://doi.org/10.1186/s40100-014-0012-3

Olarinre AA, Omonona BT. 2018. Effect of Land Fragmentation on the Productivity of Rice Farmers in Osun State, Nigeria. Applied Tropical Agriculture, 23(1): 105-111. DOI: 10.13140/RG.2.2.11854.31049.

Oluwayemisi A, Olarinde LO, Fatunbi AO. 2017. Determinants of adoption of improved maize varieties in Kano-KatsinaMaradi, West Africa. African Crop Science Journal, 25: 1-11. DOI: $10.4314 /$ acsj.v25i1.1S.

Pan D. 2014. The impact of agricultural extension on farmer nutrient management behaviour in Chinese rice production: A household-level analysis. Sustainability, 6 (10): 6644 6665. DOI: 10.3390/su6106644.

Paudel KP, Gauthier WM, Westra JV, Hall LM. 2008. Factors influencing and steps leading to the adoption of best management practices by Louisiana dairy farmers. Journal of Agricultural and Applied Economics, 40 (1): 203-222. DOI: https://doi.org/10.1017/S1074070800023555.
Pindyck RS, Rubinfeld DL. 1981. Econometric Models and Economic Forecasts. $2^{\text {nd }}$ edition, New York, McGraw-Hill Boo Co. ISBN: 978-0070500983.

Rahman S, Rahman M. 2008. Impact of land fragmentation and resource ownership on productivity and efficiency: The case of rice producers in Bangladesh. Land Use Policy, 26: 95103.

Rusinamhodzia L, Corbeels M, Nyamangara J, Giller KE. 2012. Maize-grain legume intercropping is an attractive option for ecological intensification that reduces climatic risk for smallholder farmers in central Mozambique. Field Crops Research, 136: 12-22. DOI: https://doi.org/10.1016/ j.fcr.2012.07.014

Sánchez-Toledano BI, Kallas Z, Rojas OP, Gil JM. 2018. Determinant factors of the adoption of improved maize seeds in Southern Mexico: A survival analysis approach. Sustainability, 10: 3543. DOI: https://doi.org/10.3390/ su10103543.

Sanginga PC, Tumwine J, Lilja NK. 2006. Patterns of Participation in Farmers' Research Groups: Lessons from the Highlands of Western Uganda. Agriculture and Human Values, 23(4): 501-512. DOI: 10.1007/s10460-006-9018-0.

Shiferaw B, Kassie M, Jaleta M, Yirga C. 2014. Adoption of improved wheat varieties and impacts on household food security in Ethiopia. Food Policy, 44: 272-284. DOI: 10.1016/j.foodpol.2013.09.012.

Shita A, Kumar N, Singh S. 2018. Agricultural technology adoption and its determinants in Ethiopia: a reviewed paper. Asia Pacific Journal of Research, I(LVV): 99-104.

Silva KNN, Broekel T. 2016. Factors constraining farmers' adoption of new agricultural technology programme in Hambantota District in Sri Lanka: Perceptions of Agriculture Extension Officers. 13th International Conference on Business Management, 378-398.

Smith A, Sieglinde S, Regis C, Peter TP, Mateete B, Jerry G. 2016. Measuring Sustainable Intensification in Smallholder Agroecosystems: A Review. Global Food Security, 12: 12738. DOI: https://doi.org/10.1016/j.gfs.2016.11.002.

Srivastava AK, Mboh CM, Faye B, Gaiser T, Kuhn A, Ermias E, Ewert F. 2019. Options for Sustainable Intensification of Maize Production in Ethiopia. Sustainability, 11: 1-20. DOI: https://doi.org/10.3390/su11061707.

Sun Y, Liu YZ. 2010. Evaluation of land use sustainability based on land fragmentation: A case on Fenyi County, Jiangxi Province. Journal of Natural Resources, 25(5): 802-810. DOI: http://dx.doi.org/10.17582/journal.sja/2020/36.1.217.223.

Tan S, Heerink N, Kuyvenhoven A, Qu F. 2010. Impact of land fragmentation on rice producer's technical efficiency in South-East China. NJAS-Wageningen Journal of Life Sciences, 57: 117-123. DOI: https://doi.org/10.1016/ j.njas.2010.02.001.

Tura M, Aredo D, Tsegaye W, La Rovere R, Tesfahun G, Mwangi W, Mwabu G. 2010. Adoption and continued use of improved maize seeds: Case study of Central Ethiopia. African Journal of Agricultural Research, 5(17): 2350-2358. DOI: https://doi.org/10.5897/AJAR.9000024.

Ullah A, Khan D, Zheng S, Ali U. 2018. Factors influencing the adoption of improved cultivars: a case of peach farmers in Pakistan. Ciência Rural, Santa Maria, 48: 11, e20180342, 2018. DOI: $10.1590 / 0103-8478 \mathrm{cr} 20180342$.

Zbinden S, Lee DR. 2005. Paying for environmental services: an analysis of participation in Costa Rica's PSA program. World Development, 33(2): 255-272. DOI: https://doi.org/10.1016/ j.worlddev.2004.07.012. 